\title{
Bibliometric Analysis of Islamic Economics and Finance Journals in Indonesia
}

\author{
Egi Arvian Firmansyah ${ }^{1}$, Yudi Ahmad Faisal ${ }^{2}$
}

\author{
Universitas Padjadjaran, Bandung, Indonesia 40132 \\ email: 1egi.firmansyah@unpad.ac.id, ${ }^{2}$ yudi.ahmad@unpad.ac.id
}

\begin{abstract}
For researchers in Islamic economics and finance, publishing a journal article is one of the prerequisites to enhance the discipline of Islamic economics and finance. However, to fill out the gap in current research in the field, a researcher has to review various peer-reviewed journals. This paper utilizes a bibliometric analysis through VOSviewer software to help a researcher visualizing the performance of the Islamic economics and finance journals and the researchers in the field as well as their topic of interest. This method enables a researcher with a self-developed approach in the data collection. The result of this study shows top-five Islamic economics and finance Indonesian journals, along with the ten most productive researchers. We believe there should be an improvement in the journal management and collaboration among researchers in Indonesia for the betterment of the journals in Islamic finance in the years to come.
\end{abstract}

Keywords: Authors of Islamic economics and finance articles, bibliometric analysis, Islamic economics and finance journals, Indonesia

\begin{abstract}
Abstrak. Bagi para peneliti di bidang ekonomi dan keuangan Islam, mempublikasikan artikel jurnal adalah salah satu persyaratan untuk meningkatkan ilmu ekonomi dan keuangan Islam. Tetapi untuk menganalisis kesenjangan riset di bidang keilmuan tersebut, seorang peneliti harus menelaah berbagai peer-review jurnal. Studi ini mengusulkan sebuah analisis bibliometris menggunakan software VOSviewer yang dapat membantu peneliti untuk memvisualisasikan kinerja jurnal dan para peneliti di bidang ekonomi dan keuangan Islam termasuk topik-topik penelitian yang mereka minati. Metode ini memudahkan peneliti dalam mengembangkan pendekatan personal dalam membuat koleksi data. Hasil penelitian ini menunjukkan lima besar jurnal nasional beserta sepuluh peneliti paling produktif. Diperlukan perbaikan terkait pengelolaan jurnal dan kolaborasi antarpeneliti di Indonesia untuk perbaikan jurnal-jurnal ekonomi dan keuangan Islam di masa mendatang.
\end{abstract}

Kata kunci: Analisis bibliometric, ekonomi dan keuangan Islam, Indonesia, jurnal, penulis artikel ekonomi dan keuangan Islam

\section{INTRODUCTION}

To provide a reference for the current research performance in Indonesia, the Indonesian government, through the Ministry of Research Technology and Higher Education (Kemenristekdikti) of the Republic of Indonesia established and promoted an index called Sinta (Science and Technology Index). This index was initiated in 2016 and indexes the performance of authors, researchers, journals, and research institutions (universities and non-university institutions) in the country. Sinta used Google Scholar and Scopus database as the primary sources, and it measured the performance based on these two indexes. Recently, Sinta uses Web of Science (WoS) to measure the performance of local researchers and universities.

Sinta has been one of the tools for the Government to measure the performance of universities or to rank them based on the productivity of their researchers or lecturers in producing articles, conference proceedings, books, and intellectual property rights (Hak Kekayaan Intelektual). Sinta is also employed by the Government to measure the performance of journals published by universities across Indonesia by ranking them from 1 to 6 , where 1 is for the most qualified journals (have been indexed by Scopus) and 2 to 6 for the journals which have not been indexed by Scopus.

Having qualified and reputable local journals is essential to reduce the dependence on international publishers, which often charge a substantial amount of money (commonly in foreign currencies, i.e., USD and EUR). Relying on those foreign publishers also places local universities into a state where

AL-MUZARA'AH Vol. 7 No. 2, 2019 
they are not fully independent in terms of publication.

In the field of Islamic economics and finance, it is desirable to have a suitable method to measure the performance of local journal articles. It is based on the fact that the research on Islamic economics and finance in Indonesia has started to grow. Local public universities have opened educational programs in Islamic economics and finance from bachelor to doctorate levels. Each lecturer in these universities must publish a journal article at least one in a semester to earn appropriate points in their remuneration accounts.

This research first aims at measuring the performance of Indonesian journals in the fields of Islamic economics and finance. It is essential to study those journals since the quality of local journal articles may vary and none of these journals is indexed in Sinta 1 yet. These journals are indexed in Sinta level 2 (Sinta score: 2) or accredited "B" by the local regulator (Kemenristekdikti). Secondly, this paper employs a bibliometric (or scientometrics) analysis to map the performance of Islamic economics and finance journals and researchers publishing articles in those journals, including their topic of interest.

Currently, there have been numerous researchers used the bibliometric analysis from various disciplines, such as medicine (Nafade et al., 2018), computer networking (Iqbal et al., 2019), management and business (Merigó \& Yang, 2017), digital accounting (Ardianto \& Anridho, 2018), investment (Fabregat-Aibar et al., 2019), onomastic or study about names (Aribowo, 2019), and Islamic studies in general (Hussain et al., 2016). In the field of Islamic economics and finance, Ridhwan et al. (2013) at first utilized this bibliometric analysis. They measured the performance of the Journal of Muamalat and Islamic Finance Research (JMIFR), published by Faculty of Economics and Muamalat, Universiti Sains Islam Malaysia (USIM). To best of our knowledge, the use of bibliometric analysis on Islamic economics and finance journals is still absent. The number of research and Islamic economics and finance journals is growing. Hence, this paper might be one of the pioneers to utilize bibliometric in Islamic economics and finance local journals. This research benefits the readers and researchers in Islamic economics and finance as it may fill the gap and add to the literature, particularly bibliometric analysis in the context of Indonesian Islamic economics and finance disciplines.

This paper is structured as follows. This part provides the background of this research, followed by a literature review in part two. Part three outlines the method undertaken to conduct this research. Part four describes the results and discussion, and part five provides the conclusion of this research.

\section{LITERATURE REVIEW}

\section{Bibliometric Analysis}

Bibliometric analysis is the implementation of statistics and quantitative approach for research publications (Thomson Reuters, 2008). This analysis has been employed for different purposes, areas, and topics (Aribowo, 2019; Iqbal et al., 2019; Li, 2017) or on particular journals (Abdi et al., 2018; Barik \& Jena, 2013; Jain et al., 2015; Khanna et al.,2018; Kumar, 2014; Mahalakshmi et al., 2017; Ridhwan et al., 2013; Tallolli \& Mulla, 2016; Tsay \& Shu, 2010; Wang et al., 2018; Wei, 2019).

Bibliometric analysis often uses data (or metadata) derived from Web of Science (WoS) or Scopus. These two locally well-known foreign databases are used because the number of data is enormous, and the scope of the research field is extensive. Nonetheless, this paper uses local universities' databases because none of Islamic economics and finance journals in Indonesia is already indexed in Scopus or WoS yet. Also, the use of the local database in bibliometric research is new, providing the originality of this research compared to other bibliometric research. 


\section{Islamic Economics and Finance Journals in Indonesia}

Islamic economics and finance journals are the publication media used by researchers in Islamic economics and finance field to disseminate their research. These journals facilitate the growing concern of researchers in the field. There are various sub-fields, such as Islamic finance, ethical or sharia business and management, Islamic insurance (takaful), Islamic mortgage, Islamic tourism, and others. This research selected five journals indexed in Sinta 2 and these journals are among the topfive peer-reviewed journals which regularly publish articles from local and foreign researchers, such as Malaysia, Turkey, Pakistan, and Nigeria. These journals use two common languages, Indonesian and English. However, the journals have used English in their latest issues. Therefore, authors from many countries can submit their manuscripts and anyone can read the papers.

\section{METHOD}

This research uses a bibliometric analysis to derive the planned results. The data are derived from local journals in the field of Islamic economics and finance, published by several universities in Indonesia. This research uses some criteria to select those journals. These include that the journals must be indexed by Sinta indexed by the time of this research conducted (July 2019). Considering that up to July 2019, there were no Islamic economics and finance journals indexed in Sinta 1 (Sinta score: 1), this research uses the journals indexed in Sinta 2 only (Sinta score: 2). Thus, we select five local journals, consisting of Al-IQTISHAD: Jurnal Ilmu Ekonomi Syariah, IQTISHADIA: Jurnal Kajian Ekonomi dan Bisnis Islam, SHARE: Jurnal Ekonomi dan Keuangan Islam, IKONOMIKA: Jurnal Ekonomi dan Bisnis Islam, and SHIRKAH: Journal of Economics and Business.

To measure the performance of the above-selected journals, the paper uses the h-index and citation number. $\mathrm{H}$-index is an index proposed by Jorge $\mathrm{E}$ Hirsch to measure the performance of an author initially. Hirsch (2005) stated that "A scientist has index $h$ if $h$ of his or her Np papers have at least $h$ citations each and the other $(N p \geq h)$ papers have $h$ citations each". For instance, if a researcher has an h-index of 2, he has two articles that have been cited (quoted) by other journal articles twice. Beside for measuring the performance of an author, h-index can also be used to measure the performance of a journal and we used this index to compare the performance of the journals under this study.

This research also measures the performance of the researchers publishing articles in Islamic economics and finance journals in Indonesia. To do this, we use a manual data collection technique because the readily available databases in the WoS or Scopus were not available because the journals under this study have not been indexed in those databases. The metadata in these two databases is usually exported to CSV (comma separated values) format (Aribowo, 2019; Iqbal et al., 2019). While other researchers used the database available in WoS (Ellegaard \& Wallin, 2015; Merigó \& Yang, 2017; Nafade et al., 2018), Scopus (Iqbal et al., 2019) or both of them (Fabregat-Aibar et al., 2019), this research uses the database of each journal which is open for public called an open access journal so that anyone can download the entire articles for free. This open-access mechanism allows the research articles to be downloaded by anyone having limited access to the paid database such as WoS and Scopus.

The above principles are summarized in the following steps. First, Islamic economics and finance journals indexed in Sinta 2 are selected, resulting in a different number of issues from each journal. Second, the downloaded articles are exported to Mendeley software so they could be read easily. Up to this step, it is found that many articles did not have a match metadata, as shown in the PDF format. Hence, before moving to the next steps, the data are being cleaned and fixed to match or fill the blank metadata as required by Mendeley software. Third, the metadata is exported to the RIS (Research Information System) format so that the VOSviewer software (version 1.6.11) could read it. This VOSviewer can finally visualize the metadata (Aribowo, 2019; Fabregat-Aibar et al., 2019). The above steps are summarized as follows. 

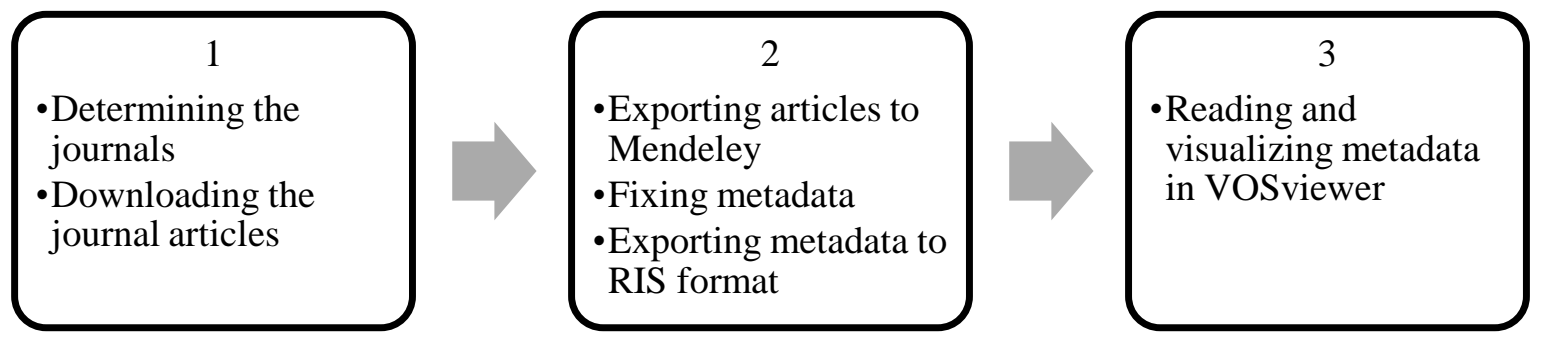

Figure 1 Research process

\section{RESULTS AND DISCUSSION}

Based on preliminary observation on Sinta website, we find that the five journals used in this study are indeed related to the field of Islamic economics and finance because they explicitly mention the word Islam and Economics (in English or Bahasa Indonesia). One of the exciting facts is that none of these journals is published by any of the most reputable local universities listed in the Ministry of Research Technology and Higher Education (Kemenristekdikti, 2018). The five Islamic economics journals in this study are published by universities under Ministry of Religious Affairs. The large and famous universities in Indonesia, based on our study, do not have Islamic Economics journals already indexed in Sinta 2.

Table 1 Journals in Islamic economics and finance indexed in Sinta 2 (accredited B)

\begin{tabular}{|c|c|c|c|c|c|c|c|}
\hline No & Journal & $\begin{array}{c}\text { Publisher } \\
\text { (university) }\end{array}$ & $\begin{array}{c}\text { Year } \\
\text { indexed in } \\
\text { Sinta } 2 \text { and } \\
\text { decree } \\
\text { number } \\
\end{array}$ & $\begin{array}{l}\text { Year of the } \\
\text { first online } \\
\text { version }\end{array}$ & $\begin{array}{l}\text { Number of } \\
\text { issues/articles } \\
\text { indexed in } \\
\text { Sinta } 2\end{array}$ & $\begin{array}{l}\text { h- } \\
\text { index }\end{array}$ & Citation \\
\hline 1 & $\begin{array}{l}\text { AL- } \\
\text { IQTISHAD: } \\
\text { Jurnal Ilmu } \\
\text { Ekonomi } \\
\text { Syariah } \\
\text { (Journal of } \\
\text { Islamic } \\
\text { Economics) }\end{array}$ & $\begin{array}{l}\text { UIN Syarif } \\
\text { Hidayatullah } \\
\text { Jakarta }\end{array}$ & $\begin{array}{l}\text { December 4, } \\
2017 \\
(51 / \mathrm{E} / \mathrm{KPT} / 2 \\
017)\end{array}$ & 2009 & $2 / 23$ & 12 & 679 \\
\hline 2 & $\begin{array}{l}\text { IQTISHADIA: } \\
\text { Jurnal Kajian } \\
\text { Ekonomi dan } \\
\text { Bisnis Islam }\end{array}$ & $\begin{array}{l}\text { STAIN } \\
\text { Kudus }\end{array}$ & $\begin{array}{l}\text { May 23, } \\
2016 \\
(36 \mathrm{~b} / \mathrm{E} / \mathrm{KPT} / \\
2016)\end{array}$ & 2013 & $6 / 55$ & 7 & 151 \\
\hline 3 & $\begin{array}{l}\text { SHARE: Jurnal } \\
\text { Ekonomi dan } \\
\text { Keuangan } \\
\text { Islam }\end{array}$ & $\begin{array}{l}\text { UIN Ar- } \\
\text { Raniry } \\
\text { Banda Aceh }\end{array}$ & $\begin{array}{l}\text { July } 9,2018 \\
(21 / \mathrm{E} / \mathrm{KPT} / 2 \\
018)\end{array}$ & 2012 & $1 / 5$ & 6 & 79 \\
\hline 4 & $\begin{array}{l}\text { IKONOMIKA: } \\
\text { Jurnal Ekonomi } \\
\text { dan Bisnis } \\
\text { Islam }\end{array}$ & $\begin{array}{l}\text { UIN Raden } \\
\text { Intan } \\
\text { Lampung }\end{array}$ & $\begin{array}{l}\text { January } 14, \\
2019 \\
(10 / \mathrm{E} / \mathrm{KPT} / 2 \\
019)\end{array}$ & 2016 & $5 / 39$ & 3 & 38 \\
\hline 5 & $\begin{array}{l}\text { SHIRKAH: } \\
\text { Journal of } \\
\text { Economics and } \\
\text { Business }\end{array}$ & $\begin{array}{l}\text { IAIN } \\
\text { Surakarta }\end{array}$ & $\begin{array}{l}\text { Jul } 9,2018 \\
(21 / \mathrm{E} / \mathrm{KPT} / 2 \\
018)\end{array}$ & 2016 & $2 / 12$ & 3 & 38 \\
\hline & Total & & & & 134 & & \\
\hline
\end{tabular}

Source: Processed data, 2019

From our observation, we find that the whole issues from the five journals are 16 issues, where each issue has a different number of published articles, as stated in their journal description. In total, 134 20 
articles/documents could be downloaded for further assessment (see Table 1). Table 1 shows that the journal of AL-IQTISHAD: Jurnal Ilmu Ekonomi Syariah, published by Universitas Islam Negeri (UIN) Syarif Hidayatullah Jakarta is the highest in terms of h-index and citation. It means this journal has relatively the highest performance among other Islamic economics and finance journals in Indonesia. It makes sense because AL-IQTISHAD is the oldest Islamic economics and finance journal in Indonesia since its online version was started in 2009, where other journals are newer, publishing their online version in 2012 until 2016. AL-IQTISHAD has the h-index of 12, which means that this journal has 12 articles that have been cited (quoted) by other journal articles 12 times. Also, this journal publishes the most articles in each issue up to 12 articles, while other articles only publish between 5-10 articles in each issue. From these results, the research finds that the journal of ALIQTISHAD has the highest performance compared to other journals of Islamic economics and finance in Indonesia. Thus, this journal is the most appropriate for the researchers in Islamic economics and finance for their publication.

Table 2 Most productive authors

\begin{tabular}{|c|c|c|c|c|}
\hline Rank & Author & $\begin{array}{c}\text { Number } \\
\text { of } \\
\text { Document }\end{array}$ & Journal Name and Citation & $\begin{array}{l}\text { Total Link } \\
\text { Strength }\end{array}$ \\
\hline 1 & Irfan Syauqi Beik & 3 & $\begin{array}{l}\text { AL-IQTISHAD (Andiani et al., } \\
\text { 2018), IQTISHADIA (Purnomo et } \\
\text { al., 2018), and IQTISHADIA } \\
\text { (Effendi et al., 2017) }\end{array}$ & 9 \\
\hline 2 & Bayu Taufik Possumah & 3 & $\begin{array}{l}\text { IKONOMIKA (Jaenudin et al., } \\
\text { 2018), IKONOMIKA (Pamuncak } \\
\text { et al., 2018), and AL-IQTISHAD } \\
\text { (Amanda et al., 2018) }\end{array}$ & 7 \\
\hline 3 & Farhan Ahmed & 3 & $\begin{array}{l}\text { AL-IQTISHAD (Abrar et al., } \\
\text { 2018), AL-IQTISHAD (Ahmed et } \\
\text { al., 2018), and IQTISHADIA } \\
\text { (Yousuf et al., 2018) }\end{array}$ & 6 \\
\hline 4 & Zakaria Bahari & 2 & $\begin{array}{l}\text { IKONOMIKA (Anuar et al., 2019) } \\
\text { and IKONOMIKA (Doktoralina et } \\
\text { al., 2018) }\end{array}$ & 6 \\
\hline 4 & $\begin{array}{l}\text { Caturida } \\
\text { Doktoralina }\end{array}$ & 2 & $\begin{array}{l}\text { IKONOMIKA (Anuar et al., 2019) } \\
\text { and IKONOMIKA (Doktoralina et } \\
\text { al., 2018) }\end{array}$ & 6 \\
\hline 4 & Abdul Qoyum & 2 & $\begin{array}{l}\text { AL-IQTISHAD (Sakti et al., 2018) } \\
\text { and IQTISHADIA (Qoyum et al., } \\
\text { 2017) }\end{array}$ & 6 \\
\hline 5 & Afzal Ahmed & 2 & $\begin{array}{l}\text { AL-IQTISHAD (Chhapra et al., } \\
\text { 2018) and AL-IQTISHAD (Ahmed } \\
\text { et al., 2018) }\end{array}$ & 5 \\
\hline 5 & Achmad Firdaus & 2 & $\begin{array}{l}\text { AL-IQTISHAD (Amanda et al., } \\
\text { 2018) and IKONOMIKA } \\
\text { (Jaenudin et al., 2018) }\end{array}$ & 5 \\
\hline 6 & $\begin{array}{l}\text { Shamsuddeen } \\
\text { Muhammad Ahmad }\end{array}$ & 1 & $\begin{array}{l}\text { IKONOMIKA (Ahmad et al., } \\
\text { 2018) }\end{array}$ & 4 \\
\hline 6 & Wan Ahmad & 1 & $\begin{array}{l}\text { IKONOMIKA (Ahmad et al., } \\
\text { 2018) }\end{array}$ & 4 \\
\hline
\end{tabular}

Source: Processed data from VOSviewer, 2019

Of the 134 articles from the selected five journals, there are 239 contributors or authors from different countries and universities. Thus, on average, each author wrote about 1.78 articles during the year 2016-2019, published in one or more of the five journals in this study. In addition, among those 239 
authors, the research finds that there are three authors who produced the most articles, namely Irfan Syauqi Beik, co-authoring three papers (Andiani et al., 2018; Effendi et al., 2017; Purnomo et al., 2018), Bayu Taufiq Possumah, co-authoring three papers (Amanda et al., 2018; Jaenudin et al., 2018; Pamuncak et al., 2018), and Farhan Ahmed, writing one paper (Ahmed et al., 2018) and co-authoring two papers (Abrar et al., 2018; Yousuf et al., 2018). Other authors wrote less than three documents, so their ranks are lower (see Table 2).

In addition to the author's productivity measurement, this research also measures the authorship pattern in VOSviewer software. Of the 239 authors, we find that there is no centralized pattern of authorship. It means the authors writing in the journals in this study are not connected. In total, there are 17 clusters with only ten authors who are included in four clusters (see Figure 3). Different colors (red, yellow, green, and blue) represent a particular cluster whereby the same color of authors representing the closest co-authorship. Figure 2 also shows that there are only four clusters, namely, cluster one consisting of Afzal Ahmed, Imran Umer Chhapra, Raja Rehan, and Farasat Hussain, cluster two consisting of Tanveer Abrar, Muhammad Kashif and Farhan Ahmed, cluster three consisting of Suman Talreja and Muhammad Waqqas Yousuf, and cluster four consisting of Abdul Rafay.

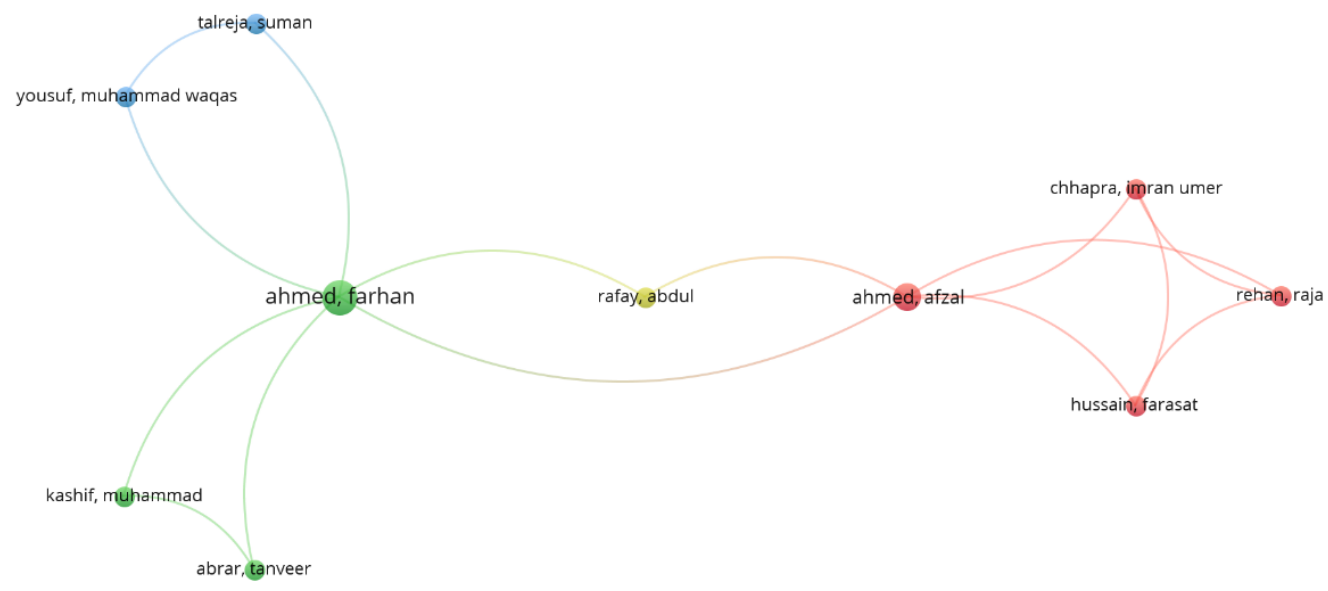

Source: Processed data, 2019

Figure 2 Co-authorship pattern

For exploring the co-authorship pattern, this research measures the keywords which are mostly used by the authors. Figure 3 shows that the authors in the journals studied in this research mostly use the term 'Islamic banking,' 'Islamic banks', and 'Islamic bank' as the keywords in their research papers. These three keywords are indeed similar and the most popular ones compared to other keywords, such as economic growth, financial stability, and satisfaction. From this result, it can be seen that most of the research produced by authors in the journals under this study relates to Islamic banking. The banking sector is the most popular among the researchers, compared to other fields such as Islamic investment, zakat, waqf, and Islamic mortgage. 


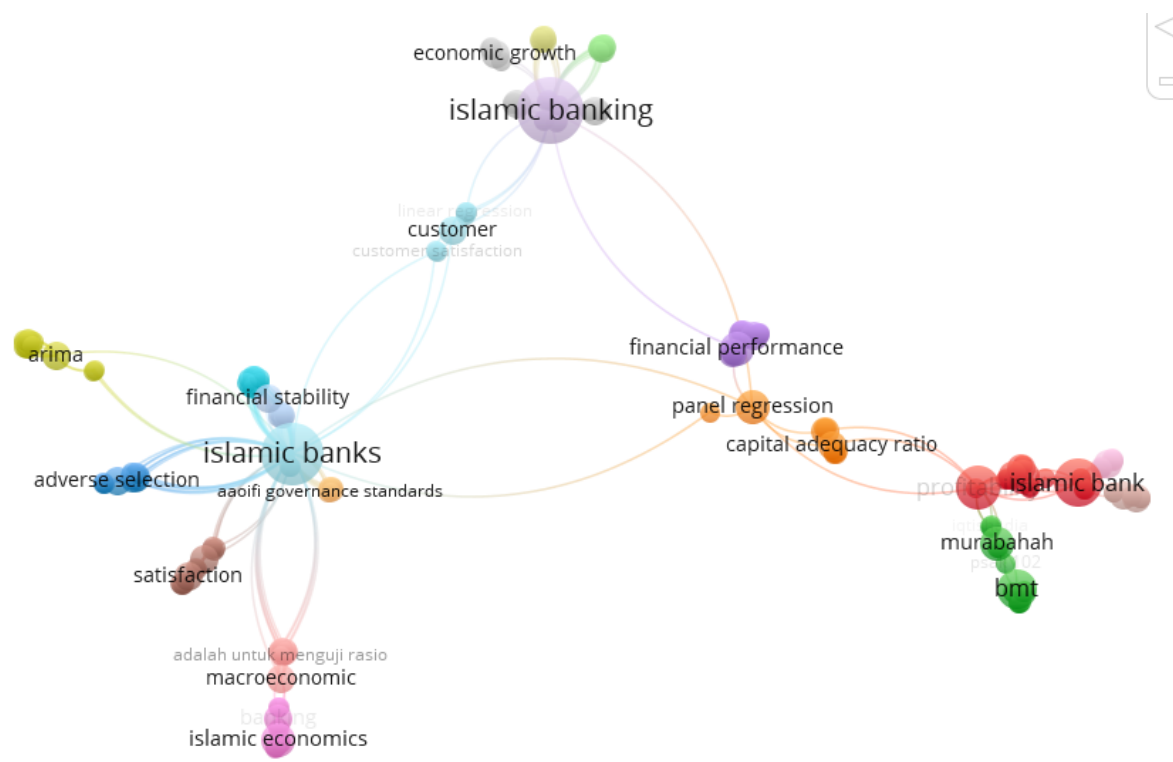

Source: Processed data, 2019

Figure 3 The most popular keywords

From the results of this research, it is clear that, first, AL-IQTISHAD is the most suitable journal as a reference for Islamic economics and finance because it has the most articles which can be downloaded for free. Besides, the researchers in Islamic economics and finance worldwide can access the articles from this journal as the language of the articles is English. Second, researchers in Islamic economics and finance need to collaborate so they can produce writings from a diverse topic. The result of this research also unveils that a study in Islamic banking is already prevalent. Thus, we believe that the researchers and journal managers need to consider publishing other topics, such as Islamic financial technology, which is still scant. Of the 134 articles in five journals in this study, we only find one article which primarily discusses Islamic financial technology (Piliyanti, 2018). Thus, the research focusing Islamic financial technology is widely open amidst its growing practice, especially in Indonesia.

\section{CONCLUSION}

Submitting articles to reputable local journals increases the competitiveness and quality of the journals. As shown in this study, the journal of AL-IQTISHAD is the oldest and has the highest performance. Thus, it is the most suitable journal for Indonesian researchers focusing on Islamic economics and finance due to its highest existence, h-index, and citations. This research also finds the most active researchers, which is Irfan Syauqi Beik. This study also shows that there is no strong coauthorship pattern among researchers, and many of them still prefer Islamic banks compared to other sectors.

This study also informs that the metadata of the selected journals is not complete. It plausibly means that editors of those journals do not pay close attention to filling this metadata, especially the keywords, journal name, volume number, and issue number. For further improvements, the journal editors need to make planned and systemic efforts as a prerequisite for a better and reputable journal publication. Besides, local researchers need to increase their joint-cooperation in writing an article, as shown in this study that the co-authorship pattern is weak. The research published in the selected five journals is also fragmented. Scholarly communication, such as conference or symposium is highly essential to be participated in encouraging co-authorship among researchers in Islamic economics and finance. 
Finally, this research is not free from drawbacks since it employed a relatively small database from the journals under this study. Further research may employ other journals, although not specifically Islamic economics and finance journals, which accept Islamic economics and finance articles. Besides, further research may utilize another broader database, such as Crossref or even WoS and Scopus for a better bibliometric analysis. Besides, further research may broaden the scope of the journals, such as studying Islamic economics and finance journals indexed in Sinta 3 or lower (accredited $\mathrm{C}$ by Kemenristekdikti) as the number of the journal in this cluster is numerous.

\section{REFERENCES}

Abdi, A., Idris, N., \& Alguliyev, R. M. (2018). Bibliometric analysis of IP\&M journal (1980 -2015). Journal of Scientometric Research, 7(1), 54-62. https://doi.org/10.5530/jscires.7.1.8.

Abrar, T., Ahmed, F., \& Kashif, M. (2018). Financial stability of Islamic versus conventional banks in Pakistan. Al-Iqtishad: Jurnal Ilmu Ekonomi Syariah (Journal of Islamic Economics), 10(2), 341-366.

Ahmad, S. M., Omar, W. A. B. W., Junoh, M. Z. B. M., Ahmad, W., \& Wan, B. (2018). The debtequity ratio choice: Risk sharing instruments, a viable alternative. IKONOMIKA: Jurnal Ekonomi dan Bisnis Islam, 3(2), 107-120.

Ahmed, F., Rafay, A., \& Ahmed, A. (2018). Dividend payout policy of conventional banking and Islamic banking in Pakistan. Al-Iqtishad: Jurnal Ilmu Ekonomi Syariah (Journal of Islamic Economics), 10(1), 135-152.

Amanda, F., Possumah, B. T., \& Firdaus, A. (2018). Consumerism in personal finance: An Islamic wealth management approach. Al-Iqtishad: Jurnal Ilmu Ekonomi Syariah (Journal of Islamic Economics), 10(2), 325-340.

Andiani, K., Hafidhuddin, D., Beik, I. S., \& Ali, K. M. (2018). Strategy of BAZNAS and Laku Pandai for collecting and distributing zakah in Indonesia. Al-Iqtishad: Jurnal Ilmu Ekonomi Syariah (Journal of Islamic Economics), 10(2), 417-440.

Anuar, A. S., Bahari, Z., Doktoralina, C. M., Indriawati, F., \& Nugroho, L. (2019). The diversity of waqf implementations. IKONOMIKA: Jurnal Ekonomi dan Bisnis Islam, 4(1), 13-34.

Ardianto, A. \& Anridho, N. (2018). Bibliometric analysis of digital accounting. The International Journal of Digital Accounting Research, 18(May), 141-159. https://doi.org/10.4192/1577-8517v18.

Aribowo, E. K. (2019). Analisis bibliometrik berkala ilmiah names: Journal of Onomastics dan peluang riset onomastik di Indonesia. Jurnal Aksara, 31(1), 91-111. https://doi.org/10.6084/m9.figshare.7797371.v1.

Barik, N. \& Jena, P. (2013). Bibliometric analysis of journal of knowledge management practice, 2008-2012. Library Philosophy and Practice (e-journal), 1020.

Chhapra, I. U., Ahmed, A., Rehan, R., \& Hussain, F. (2018). Consumer's preference and awareness: Comparative analysis between conventional and Islamic ijarah auto financing in Pakistan. $A l$ Iqtishad: Jurnal Ilmu Ekonomi Syariah (Journal of Islamic Economics), 10(2), 389-402.

Doktoralina, C. M., Bahari, Z., \& Abdullah, S. R. (2018). Mobilisation of income zakat payment in Indonesia. IKONOMIKA: Jurnal Ekonomi dan Bisnis Islam, 3(2), 189-204.

Effendi, J., Baga, L. M., Beik, I. S., \& Nursyamsiah, T. (2017). Aplikasi model bisnis microfinance syariah terhadap sektor UMKM di Indonesia. Iqtishadia, 10(2), 120-152. https://doi.org/10.21043/iqtishadia.v10i2.2241

Ellegaard, O. \& Wallin, J. A. (2015). The bibliometric analysis of scholarly production: How great is the impact? Scientometrics, 105(3), 1809-1831. https://doi.org/10.1007/s11192-015-1645-z.

Fabregat-Aibar, L., Barberà-Mariné, M. G., Terceño, A., \& Pié, L. (2019). A bibliometric and visualization analysis of socially responsible funds. Sustainability, 11(9), 2526. https://doi.org/10.3390/su11092526.

Hirsch, J. E. (2005). An index to quantify an individual's scientific research output. In National Academy of Sciences of the United States of America, 102, 16569-16572.

Hussain, A., Ibrahim, M., Saeed, S., \& Pakhtunkhwa, K. (2016). A bibliometric analysis of contributions in Islamic studies (journal): 2009-2011. 
Iqbal, W., Qadir, J., Tyson, G., Mian, A. N., Hassan, S. U., \& Crowcroft, J. (2019). A bibliometric analysis of publications in computer networking research. Scientometrics, 119(2), 1121-1155. https://doi.org/10.1007/s11192-019-03086-z

Jaenudin, D., Firdaus, A., Afendi, F. M., \& Possumah, B. T. (2018). Analysis of ta'awun fund model best practice from Indonesia. IKONOMIKA: Jurnal Ekonomi dan Bisnis Islam, 3(2), 139-166.

Jain, S., Basavaraj, P., Singla, A., Singh, K., \& Kundu, H. (2015). Bibliometric analysis of Journal of Clinical and Diagnostic Research (Dentistry Section; 2007-2014 ). Journal of Clinical and Diagnostic Research, 9(4), 8-12. https://doi.org/10.7860/JCDR/2015/11994.5834.

[Kemenristekdikti] Kementerian Riset, Teknologi, dan Pendidikan Tinggi. (2018). Kemenristekdikti Umumkan Peringkat 100 Besar Perguruan Tinggi Indonesia Non Vokasi Tahun 2018 Ristekdikti. Retrieved July 4, 2019, from https://ristekdikti.go.id/kabar/kemenristekdiktiumumkan-peringkat-100-besar-perguruan-tinggi-indonesia-non-vokasi-tahun-2018/

Khanna, S., Bansal, J., Sood, S., \& Tiwari, D. (2018). Journal of Academic Librarianship: A bibliometric analysis. International Journal of Library Information Network and Knowledge, $3(2), 123-133$.

Kumar, M. (2014). Library Herald Journal : A bibliometric study. Journal of Education \& Social Policy, 1(2), 123-134.

Li, M. T. C. (2017). Bibliometric analysis of the journal literature on women's studies. Scientometrics, 113(2), 705-734. https://doi.org/10.1007/s11192-017-2493-9

Mahalakshmi, G. S., Selvi, G. M., \& Sendhilkumar, S. (2017). A bibliometric analysis of Journal of Informetrics - A decade study 1. In Second International Conference on Recent Trends and Challenges in Computational Models (pp. 222-227). https://doi.org/10.1109/ICRTCCM.2017.22

Merigó, J. M. \& Yang, J. B. (2017). A bibliometric analysis of operations research and management science. Omega (United Kingdom), 73, 37-48. https://doi.org/10.1016/j.omega.2016.12.004

Nafade, V., Nash, M., Huddart, S., Pande, T., Gebreselassie, N., Lienhardt, C., \& Pai, M. (2018). A bibliometric analysis of tuberculosis research, 2007-2016. PLOS ONE, 13(6), 2007-2016. https://doi.org/10.1371/journal.pone.0199706

Pamuncak, M. B., Possumah, B. T., \& Halim, Z. A. (2018). IFRS based zakat reporting: Adoption Rational Western Method into institutional accountability. IKONOMIKA: Jurnal Ekonomi dan Bisnis Islam, 3(1), 17-34.

Piliyanti, I. (2018). Fintech achieving sustainable development the side perspective of crowdfunding platform. Shirkah: Journal of Economics and Business, 3(2), 223-241. https://doi.org/ 10.22515/shirkah.v3i2.207.

Purnomo, H., Dharmawan, A. H., Hubeis, A. V., \& Beik, I. S. (2018). Intellectual capital approach for a better corporate governance of sharia banking. Iqtishadia, 11(1), 105-128. https://doi.org/10.21043/iqtishadia.v10i2.2863

Qoyum, A., Mutmainah, L., Setyono, J., \& Qizam, I. (2017). The impact of good corporate governance , company size nn corporate social responsibility disclosure: Case study of Islamic banking in Indonesia. Iqtishadia, 10(1), 103-159.

Ridhwan, M., Johari, F., \& Yusoff, M. M. (2013). Eight years of Journal of Muamalat and Islamic Finance Research (JMIFR) (2004-2011): A way forward. Library Philosophy and Practice, 119.

Sakti, M. R. P., Thaker, H. bin M. T., Qoyum, A., \& Qizam, I. (2018). The concept and practices of macroprudential policy in Indonesia: Islamic and conventional. Al-Iqtishad: Jurnal Ilmu Ekonomi Syariah (Journal of Islamic Economics), 10(1), 75-96.

Tallolli, S. B. \& Mulla, K. R. (2016). A bibliometric analysis of journal of information literacy (2011 to 2015). ISST Journal of Advances in Librarianship, 7(2), 44-51.

Thomson Reuters. (2008). Whitepaper Using Bibliometrics. Thomson Reuters. https://doi.org/10.1097/NCN.0b013e31819ec9ac

Tsay, M. \& Shu, Z. (2010). Journal bibliometric analysis: A case study on the Journal of Documentation. Journal of Documentation, 67(5), 806-822. https://doi.org/10.1108/00220411111164682

Wang, W., Laengle, S., Yu, D., Herrera-viedma, E., Cobo, M. J., \& Bouchon-meunier, B. (2018). A 
bibliometric analysis of the first twenty-five years of the International Journal of Uncertainty, Fuzziness and Knowledge-Based Systems. International Journal of Uncertainty, Fuzziness and Knowledge-Based Systems, 26(2), 169-193. https://doi.org/10.1142/S0218488518500095

Wei, G. (2019). A bibliometric analysis of the top five economics journals during 2012-2016. Journal of Economic Surveys, 33(1), 25-59. https://doi.org/10.1111/joes.12260

Yousuf, M. W., Ahmed, F., \& Talreja, S. (2018). Assessing the impact of service quality on consumers satisfaction: A comparative study of commercial v/s Islamic banks in Pakistan. Iqtishadia, 11(2). https://doi.org/10.21043/iqtishadia.v11i2.3595 